\title{
Morpho-biological features of rosewort(rhodiola rosea I.) under the conditions of introduction
}

\author{
M. Y. Karpukhin ${ }^{1}$, and A. V. Abramchuk ${ }^{1}$ \\ ${ }^{l}$ Ural State Agrarian University, 620075, Karla Libknekhta str.,42, Yekaterinburg, Russia
}

\begin{abstract}
The uncontrolled harvesting of rosewort has led to a sharp decline in its natural populations in the Nether-Polar Urals, and in a number of places in Altai and Sayany - to almost complete extermination of the plant. Nowadays rosewort is classified as rare and endangered species, in many regions - as a protected plant. One reliable way to preserve this plant is to introduce it into culture.

The article presents the results obtained during the experiment (during 2010-2014) on the study of morpho-biological features of rosewort(Rhodiolarosea) L.) under the conditions of introduction. Theexperimental design included 3 options, differing in the area of nutrition: 1 var. $-50 \times 50 \mathrm{~cm}\left(4\right.$ plants $\left./ \mathrm{m}^{2}\right)$, taken for control; 2 var. -33 x $\left.50 \mathrm{~cm}(6 \text { plants } / \mathrm{m})^{2}\right) ; 3$ var. $-25 \times 50 \mathrm{~cm}\left(8\right.$ plants $\left./ \mathrm{m}^{2}\right)$.

During the study, the optimal growing space was established - 50x50 $\mathrm{cm}$, at which, during all years of observation, there was a more active growth of rosewort plants. Seasonal development process in all variants is represented by a single-vertex curve, with a pronounced maximum, the magnitude of which depended on the average daily growth of plants. The highest average daily increase in the experiment was observed in different terms: in the 1st var. - in the second decade of June; in the 2nd var. - in the third decade of June; in the 3rd var. - in the first decade of July; it varied from $1.28 \mathrm{~cm}$ (3 var.) to $1.71 \mathrm{~cm}$ (1 var.).
\end{abstract}

\section{Introduction}

Rosewort (Rhodiolarosea L.) is an extremely polymorphic species. some of its geographic races have already been allocated to the rank of independent species [4]. On the territory of Russia the main center of distribution of rosewort are mountains of Southern Siberia: Altai, Kuznetsk Alatau, Western and Eastern Sayany, Tuva mountains. It has a wide Eurasian arcto-highland range. Depending on the habitat conditions, within significant limits rosewort changes such signs as the height of shoots, shape and size of leaves, number of flowers, strength of the root system [5]. Streek and river valleys and moist highland meadows serve as the optimum habitats of rosewort. In the conditions of the Alpine highland belt, the plant occurs at an altitude of up to 2300-2400 $\mathrm{m}$ above sea level $[1,7]$.

In the Middle Urals, rosewort is common in mountain tundra and on bald mountains, stony slopes and rock slides in the Ivdelsk foothill district [1,7]. Moisturization and soil type are the most important environmental factors for rosewort growth. 
Rosewort (Rhodiolarosea L.) (golden root), stonecrop family (CrassulaceaeDC) is a perennial plant.

The root system of rosewort consists of a branching rhizome and numerous roots. The size and weight of rhizomes vary greatly depending on plant habitats. The average weight of rhizomes ranges from 70 to $400 \mathrm{~g}$, and the maximum weight reaches $2.5-3.5 \mathrm{~kg}$ [6]. In the process of life, rosewort's rhizomes annually grow from above and break down from below. The surface of the rhizomes is smooth, beige in colour with golden glisten. The odor is characteristic, a little reminiscent of rose attar. The taste is bitter-astringent.

The medicinal raw materials in rosewort are rhizomes with roots that are harvested in the period from the end of flowering to the end of plant vegetation. Rosewort roots and rhizomes contain tannins (up to $20 \%$ ), anthraglycosides, essential oil, organic and phenolic acids, significant amounts of sugars, proteins, fats, waxes, sterols, glycosides, flavonoids and large amounts of manganese. The main active substances of the plant's roots are phenolalcoholtyrosol and its glycoside salidroside (rhodioloside) [6].

Rosewortis a valuable adaptogeneplant, rhodiola preparations have a stimulating effect on mental performance, improve memory and attention $[3,8]$. By stimulating action rosewort is superior to lemongrass, maralium root, eleutherococcus. In recent years, the researches have shown antitumor activity and antioxidant effect of the root $[10,11]$. The therapeutic properties of rosewort are highly valued in Eastern medicine (China, Mongolia, Tibet, Japan [7].

The need for medicinal raw materials of Rosewortin Russia is covered mainly by harvesting wild plants, while the ecological purity of medicinal raw materials is not ensured, and the real possibility of exploiting natural thickets of Golden root is not taken into account. The uncontrolled harvesting of rosewort has led to a sharp decline in its natural populationsin the Nether-Polar Urals, and in a number of places in Altai and Sayany - to almost complete extermination of the plant. Nowadays rosewort is assigned to rare and endangered species, in many regions - to protected plants [7]. One of the reliable ways to preserve this plant in nature is its introduction. [2,9].

\section{Methods of research.}

The study on the topic "Morpho-biological features of rosewortRhodiolarosea L. in the conditions of introduction" was conducted in "Uralets" experimental farm, located in Beloyarsky District, Sverdlovsk Oblast. The experiment was laid out in spring (May 4) 2010. Soil on the experimental site - heavy loamy podzolized chernozem. This type of soil is characterized by deep carbonate horizon deposits and signs of podzolization. Horizon depth $\mathrm{A}-40-45 \mathrm{~cm}, \mathrm{AB}_{1}-60-80 \mathrm{~cm}$. The humus horizon is enriched with exchange bases, $70 \%$ of which is calcium. The reaction of the medium is close to neutral ( $\mathrm{pH}-6.5)$. The soil of the site is characterized by high availability of macronutrients - phosphorus, potassium, nitrogen. The predecessor - bare fallow, in autumn 2009 deep tillage was carried out; in spring 2010 - cultivation followed by harrowing.

The experimental design includes 3 variants, differing in the area of nutrition: 1 var. $-50 \times 50$ $\mathrm{cm}\left(4\right.$ plants $\left./ \mathrm{m}^{2}\right)$, taken for control; 2 var. $-33 \times 50 \mathrm{~cm}\left(6\right.$ plants $\left./ \mathrm{m}^{2)}\right), 3$ var. $-25 \times 50 \mathrm{~cm}(8$ plants/ $\mathrm{m}^{2}$ ). The area is $2 \mathrm{~m}^{2}$, the repetition is four times. Current care included 2-3 interrow treatments, weeding.

Purpose of the study: to identify the effect of the nutrition area on the growth and development of rosewort. Objectives: to study the effect of the nutrition area on phenological phases and the timing of their passage; peculiarities of shoots regrowth, morphological characteristics.

Rhizomes of rosewort, harvested on the KonzhakovskiyKamen mountain, which is located in the Konzhakovsky highland district in the watershed part of the mountain Urals, were used for the study. The natural population of the golden root is common in the mountain tundra belt (900-1400 
$\mathrm{m}$ above sea level) on mountain meadow podzolized and primitive accumulative mountain tundra soils.

The clump rhizomes (before planting) were cut into several parts, each of which had a root system and at least 2-3 reopening buds. Before planting, the cuts were treated with a weak solution of manganese acid potassium.

\section{Results of the study}

Golden root is characterized by high cold tolerance. Begins growing under the snow cover, as soon as the snow goes down the plants immediately start growing. In the 1st var., where the growing space was $50 \times 50 \mathrm{~cm}\left(4\right.$ plants $\left./ \mathrm{m}^{2}\right)$, the growth of plants was more intense, according to all accounting dates the plants were significantly higher than in other variants (Table 1). Active linear growth was observed in June, in the first decade of August the average height of plants was $47 \mathrm{~cm}$. The average daily increase in the first half of vegetation (May-June) for all accounting dates was substantially higher than in other variants. The maximum growth of plants was noted in the second decade of June, the value reached $1.71 \mathrm{~cm}$ per day.

Table 1. Dynamics of height and average daily growth of Rhodiolarosea L., 2014

\begin{tabular}{|c|c|c|c|c|c|c|c|c|c|}
\hline \multirow{3}{*}{$\begin{array}{l}\text { Experiment variants } \\
\text { (growing space) }\end{array}$} & \multirow[t]{3}{*}{ Indicators, $\mathrm{cm}$} & \multicolumn{8}{|c|}{ Accounting dates } \\
\hline & & \multicolumn{3}{|c|}{ May } & \multicolumn{2}{|l|}{ June } & \multicolumn{2}{|l|}{ July } & \multirow{2}{*}{$\begin{array}{r}\begin{array}{c}\text { Aug } \\
\text { ust }\end{array} \\
8\end{array}$} \\
\hline & & 2 & 16 & 30 & 13 & 27 & 11 & 25 & \\
\hline \multirow[b]{2}{*}{$\begin{array}{l}1 \text { st var. }-50 \times 50 \mathrm{~cm} \\
\left(4 \text { plants } / \mathrm{m}^{2}\right)\end{array}$} & height & 5 & 10 & 16 & 28 & 38 & 44 & 46 & 47 \\
\hline & $\begin{array}{l}\text { average daily } \\
\text { growth }\end{array}$ & - & 0.71 & 0.86 & 1.71 & 1.43 & 0.86 & 0.28 & 0.14 \\
\hline \multirow[b]{2}{*}{$\begin{array}{l}\text { 2nd var. }-33 \times 50 \mathrm{~cm} \\
\left(6 \text { plants } / \mathrm{m}^{2}\right)\end{array}$} & height & 4 & 5 & 10 & 17 & 27 & 33 & 37 & 40 \\
\hline & $\begin{array}{l}\text { average daily } \\
\text { growth }\end{array}$ & - & 0.14 & 0.71 & 1.0 & 1.43 & 0.86 & 0.57 & 0.43 \\
\hline \multirow{2}{*}{$\begin{array}{l}\text { 3rd var. }-25 \times 50 \mathrm{~cm} \\
\left(8 \text { plants } / \mathrm{m}^{2}\right)\end{array}$} & height & 3 & 4 & 7 & 10 & 15 & 24 & 28 & 31 \\
\hline & $\begin{array}{l}\text { average daily } \\
\text { growth }\end{array}$ & - & 0.14 & 0.43 & 0.43 & 0.71 & 1.28 & 0.57 & 0.43 \\
\hline
\end{tabular}

Low rates had plants in the $3 \mathrm{rd}$ var. $(25 \times 50 \mathrm{~cm})$ : less active growth of plants throughout the growing season; plant height is significantly lower than in other studied variants; in the first decade of August, plants were $9 \mathrm{~cm}$ lower than in the second variant and $16 \mathrm{~cm}$ lower than in the first variant.

Since the third decade of July, the growth of rosewort in height decreased markedly, and since the second decade of August stopped in all variants, by this period the plants differed quite significantly in height: the most undersized shoots were noted in the 3rd variant.

In general, the course of seasonal development in all variants is represented by a single-vertex curve with a pronounced maximum, the value of which depended on the average daily growth of plants. The highest average daily increase in the experiment was observed in different terms: in the 1st var. - in the second decade of June; in the 2nd var. — in the third decade of June; in the 3rd var. - in the first decade of July. In the experiment, the average daily growth ranged from $1.28 \mathrm{~cm}$ (3rd var.) to $1.71 \mathrm{~cm}$ (1st var.). 
During the study, observations were made on phenological phases and the timing of their passage. From the data given in Table 2 it is clear that the rosewort is characterized by early spring regrowth. The plant begins to grow as soon as the snow melts. The most active vegetation of plants was in the control variant $(50 \times 50 \mathrm{~cm})$, at the end of May - in the first decade of June there was a transition to the generative stage of development (budding and the beginning of flowering in individual plants). The beginning of fruiting was observed in late June, and the mass transition to fruiting was observed in the first decade of July. During the harvesting period of underground biomass (third decade of August), most of the shoots ( $80-85 \%)$ were in the dieback phase, which was accompanied by shoots browning and falling leaves, the shoots easily separated from the rhizome. It should be noted that in the bush of rosewort there is regrowth of new shoots (summerautumn generation) and even at the end of growing there is a fairly significant number of them.

Table 2, Phenological phases and timing of their passage of Rhodiolarosea L. 2014

\begin{tabular}{|l|c|c|c|}
\hline \multirow{2}{*}{\begin{tabular}{c}
\multirow{2}{*}{$\begin{array}{c}\text { Phenological } \\
\text { phases }\end{array}$} \\
\cline { 2 - 4 } 1. Spring regrowth
\end{tabular}} & $\begin{array}{c}\text { 1st var. - 50x50 cm } \\
\left(4 \text { plants } / \mathrm{m}^{2}\right)\end{array}$ & $\begin{array}{c}\text { 2nd var. }-33 \times 50 \mathrm{~cm} \\
\left(6 \text { plants } / \mathrm{m}^{2}\right)\end{array}$ & $\begin{array}{c}\text { 3rd var. }-25 \times 50 \mathrm{~cm} \\
\left(8 \mathrm{plants} / \mathrm{m}^{2}\right)\end{array}$ \\
\hline 2. Budding & 4.05 & 4.05 & 4.05 \\
\hline $\begin{array}{l}\text { 3. Flowering: } \\
\text { beginning }\end{array}$ & 25.05 & 28.05 & 13.06 \\
\hline $\begin{array}{l}\text { massive } \\
\text { 4. Fruiting: } \\
\text { beginning }\end{array}$ & 20.06 & 17.06 & 26.06 \\
\hline massive & 27.06 & 23.06 & 2.07 \\
\hline
\end{tabular}

In the second variant where the growing space was $33 \times 50 \mathrm{~cm}$, seasonal development showed the same trends as in the first variant; the differences in the study years were extremely insignificant. In 2014, there was a slight lag in the transition to the generative development stage.

In the third variant $(25 \times 50 \mathrm{~cm})$, plants were significantly behind in their development. For all the years of the study, a slower rate of plant development is characterized: transition to the generative stage was observed 1.5-2 weeks later than in other variants.

Analysis of the obtained results showed that phenological phases and the timing of their passage are closely dependent on the growing space. The best results are obtained in the control variant, where the growing space was $50 \times 50 \mathrm{~cm}$, in which all processes of growth and development of rosewort passed more intensively, phenological phases occured earlier.

In the experiment, the effect of growing space on biometric indicators of the generative shoot of rosewort was traced. By the number of shoots and the rate of their regrowth, it is possible to judge how much plants have adapted to new habitat conditions. According to literary data, the number of stems (shoots) in rosewort varies widely: from 1 to 100 pieces and more per specimen.

Table 3 shows that the best results were provided by the first variant $(50 \times 50 \mathrm{~cm})$, where 4 plants/ m2were planted, a larger number of shoots $(81 \mathrm{pcs} / 1$ specimen). This variant is characterized by the highest generativity $-69.1 \%$. Close results are obtained in the second variant $(33 \times 50 \mathrm{~cm})$.

Table 3, Biometric indicators of Rhodiolarosea L. generative shoot.(average for 2012-2014) 


\begin{tabular}{|c|c|c|c|c|c|c|}
\hline \multirow{3}{*}{$\begin{array}{l}\text { Experiment variants } \\
\text { (growing space) }\end{array}$} & \multicolumn{5}{|c|}{ Number of shoots (average /1 specimen) } & \multirow{3}{*}{$\begin{array}{c}\text { Total } \\
\text { shoot } \\
\text { mass, g }\end{array}$} \\
\hline & \multicolumn{2}{|l|}{ generative } & \multicolumn{2}{|l|}{ vegetative } & \multirow{2}{*}{$\begin{array}{l}\begin{array}{l}\text { total } \\
\text { shoots } \\
\text { number }\end{array} \\
\text { pcs./per 1 } \\
\text { specimen }\end{array}$} & \\
\hline & $\begin{array}{l}\text { pcs./per } 1 \\
\text { specimen }\end{array}$ & $\%$ & $\begin{array}{l}\text { pcs./per } 1 \\
\text { specimen }\end{array}$ & $\%$ & & \\
\hline $\begin{array}{l}\text { 1st var. }-50 \times 50 \mathrm{~cm} \\
\left(4 \text { plants } / \mathrm{m}^{2}\right)\end{array}$ & 56 & 69.1 & 25 & 30.9 & 81 & 24.2 \\
\hline $\begin{array}{l}\text { 2nd var. }-33 \times 50 \mathrm{~cm} \\
\left(6 \text { plants } / \mathrm{m}^{2}\right)\end{array}$ & 48 & 63.2 & 28 & 36.8 & 76 & 20.8 \\
\hline $\begin{array}{l}\text { 3rd var. }-25 \times 50 \mathrm{~cm} \\
\left(8 \text { plants } / \mathrm{m}^{2}\right)\end{array}$ & 17 & 37.8 & 28 & 62.2 & 45 & 14.6 \\
\hline
\end{tabular}

The lowest characteristics are noted in the third variant ( 8 plants $/ \mathrm{m} 2)$ : the total number of shoots was 45 pcs/1 specimen, which is 36 shoots (55.6\%) less than in control. Generativity is substantially lower, vegetative shoots prevail. It should be noted that plants in the studied variants vary significantly in the mass of shoots: in the control version the mass of shoot is $9.6 \mathrm{~g} \mathrm{(39.7:) \%}$ greater than in the third variant.

Differences were also observed in biometric indicators of leaves, the best characteristics were rosewort plants in the control variant: the maximum number of leaves - $59 \mathrm{pcs} / 1$ specimen, which is $47.5 \%$ more, than in the $3 \mathrm{rd}$ var.; length and width are substantially higher than in other variants studied. (Table 4).

Table 4, Biometric characteristics of rosewort leaves(average for 2012-2014)

\begin{tabular}{|l|c|c|c|}
\hline \multirow{2}{*}{$\begin{array}{l}\text { Experiment } \\
\text { variants } \\
\text { (growing space) }\end{array}$} & $\begin{array}{c}\text { number, } \\
\text { pcs/1 shoot }\end{array}$ & $\begin{array}{c}\text { length, } \\
\mathrm{cm}\end{array}$ & $\begin{array}{c}\text { width, } \\
\mathrm{cm}\end{array}$ \\
\cline { 2 - 4 } & $59 \pm 1,45$ & $3.64 \pm 0.06$ & $1.7 \pm 0.03$ \\
\hline $\begin{array}{l}\text { 1st var. }-50 \times 50 \mathrm{~cm} \\
\left(4 \text { plants } / \mathrm{m}^{2}\right)\end{array}$ & $48 \pm 1,59$ & $3.52 \pm 0.07$ & $1.5 \pm 0.03$ \\
\hline $\begin{array}{l}\text { 2nd var. }-33 \times 50 \\
\mathrm{~cm} \\
\left(6 \text { plants } / \mathrm{m}^{2}\right)\end{array}$ & $31 \pm 1,73$ & $2.41 \pm 0.09$ & $1.1 \pm 0.04$ \\
\hline $\begin{array}{l}3 \mathrm{rd} \text { var. }-25 \times 50 \mathrm{~cm} \\
\left(8 \text { plants } / \mathrm{m}^{2}\right)\end{array}$ & & \\
\hline
\end{tabular}

In the structure of generative shoot, all variants are dominated by leaves, their participation ranges from $67.4 \%$ (1st var.) to $74.5 \%$ (3rd var.). The involvement of the stem varies from $22.1 \%$ (3rd var) to $26.4 \%$ (1st var.). The proportion of inflorescences in the structure of generative shoot is obtained higher in the control variant $-6.2 \%$ of the total mass of generative shoot (Table 5).

Table 5, Structural composition of Rhodiolarosea L. overground biomass(average for 2012-2014)

\begin{tabular}{|l|c|c|c|}
\hline \multirow{2}{*}{$\begin{array}{l}\text { Experiment variants } \\
\text { (growing space) }\end{array}$} & \multicolumn{3}{|c|}{ Overground biomass } \\
\cline { 2 - 4 } & leaves & inflorescences & stems \\
\hline
\end{tabular}




\begin{tabular}{|l|c|c|c|c|c|c|}
\hline & mass, $\mathrm{g}$ & $\%$ & mass, $\mathrm{g}$ & $\%$ & mass, $\mathrm{g}$ & $\%$ \\
\hline $\begin{array}{l}\text { 1st var. }-50 \mathrm{x} 50 \mathrm{~cm} \\
\left(4 \text { plants } / \mathrm{m}^{2}\right)\end{array}$ & 16.3 & 67.4 & 1.5 & 6.2 & 6.4 & 26.4 \\
\hline $\begin{array}{l}\text { 2nd var. }-33 \times 50 \mathrm{~cm} \\
\left(6 \text { plants } / \mathrm{m}^{2}\right)\end{array}$ & 14.5 & 69.7 & 1.1 & 5.3 & 5.2 & 25.0 \\
\hline $\begin{array}{l}\text { 3rd var. }-25 \times 50 \mathrm{~cm} \\
\left(8 \text { plants } / \mathrm{m}^{2}\right)\end{array}$ & 10.9 & 74.5 & 0.5 & 3.4 & 3.2 & 22.1 \\
\hline
\end{tabular}

As a medicinal raw material, rosewort's underground biomass is mainly used - rhizomes with roots that are harvested from the end of flowering to the end of plant vegetation. It is in the underground biomass that the largest amount of biologically active substances are concentrated, which are widely used in medical practice [4,10,11].

The productivity of the underground mass was determined in 2012 and 2014 in late Augustearly September, when the active dieback process of overground shoots began. The dug rhizomes were cleaned of soil particles, the overground shoots cut off, then quickly laundered in running water. Then the filter paper removed excess moisture, after pre-drying (for 5-7 hours) it was weighed. The results obtained in the experiment are presented in Table 6, which shows that in 2012 the lowest productivity was formed in the control variant, where 4 plants $/ \mathrm{m} 2$ were planted. In 2014 , there was an active increase in underground biomass in the first and second variants. Compared to 2012, the increase ranged from $0.68 \mathrm{~kg} / \mathrm{m} 2$ (2nd var) to $0.82 \mathrm{~kg} / \mathrm{m} 2$ (1st var). Significantly lower was the increase in the third variant, it was only $0.37 \mathrm{~kg} / \mathrm{m} 2$.

Table 6, The productivity of Rhodiolarosea $\mathrm{L}$. underground biomass

\begin{tabular}{|c|c|c|c|c|c|c|}
\hline \multirow{4}{*}{$\begin{array}{l}\text { Experiment } \\
\text { variants } \\
\text { (growing space) }\end{array}$} & \multicolumn{6}{|c|}{ Overground biomass } \\
\hline & \multicolumn{3}{|c|}{2012} & \multicolumn{3}{|c|}{2014} \\
\hline & \multirow{2}{*}{$\begin{array}{l}\text { producti } \\
\text { vity, } \\
\mathrm{kg} / \mathrm{m}^{2}\end{array}$} & \multicolumn{2}{|c|}{$\begin{array}{l}\text { deviation from } \\
\text { control, }(+,-)\end{array}$} & \multirow{2}{*}{$\begin{array}{l}\text { producti } \\
\text { vity, } \\
\mathrm{kg} / \mathrm{m}^{2}\end{array}$} & \multicolumn{2}{|c|}{$\begin{array}{l}\text { deviation from } \\
\text { control, }(+,-)\end{array}$} \\
\hline & & $\mathrm{kg} / \mathrm{m}^{2}$ & $\%$ & & $\mathrm{~kg} / \mathrm{m}^{2}$ & $\%$ \\
\hline $\begin{array}{l}\text { 1st var. - } \\
50 \times 50 \mathrm{~cm} \\
\left(4 \text { plants } / \mathrm{m}^{2}\right)\end{array}$ & 1.29 & - & - & 2.11 & - & - \\
\hline $\begin{array}{l}\text { 2nd var. - } \\
33 \times 50 \mathrm{~cm} \\
\left(6 \text { plants } / \mathrm{m}^{2}\right)\end{array}$ & 1.47 & +0.18 & 14.0 & 2.15 & +0.04 & 1.9 \\
\hline $\begin{array}{l}\text { 3rd var. - } \\
25 \times 50 \mathrm{~cm} \\
\left(8 \text { plants } / \mathrm{m}^{2}\right)\end{array}$ & 1.44 & +0.15 & 11.6 & 1.81 & -0.3 & 14.2 \\
\hline $\mathrm{NSR}_{05}$ & 0.03 & - & - & 0.05 & - & - \\
\hline
\end{tabular}




\section{Conclusion}

The study leads to the conclusion that the growing space is the most important factor influencing the growth and development of rosewort. During the experiment it was established that the first variant was optimal, where the growing space was $50 \times 50 \mathrm{~cm}(4$ plants $/ \mathrm{m} 2)$ : the processes of growth and development of rosewort passed more intensely, phenological phases occured earlier; more sprouts were formed ( $81 \mathrm{pcs} / 1$ specimen); high generativity $-69.1 \%$. The best biometric characteristics of leaves were shown by rosewort plants in the control variant: maximum number of leaves - 59 pcs/1 specimen, which is $47.5 \%$ more than the 3rd var.; length and width were substantially higher than in other variants under consideration. Close results are obtained in the second variant $(33 \times 50 \mathrm{~cm})$.

The productivity of underground biomass in 2014 was almost the same in the first and second variants, and differences between these variants are not significant.

\section{References}

1. A.V. Abramchuk, S. K. Mingalev, Cultivated medicinal plants. Range, properties, technology of cultivation, 292 (2004)

2. A.V. Abramchuk, Features of growth and development of rosewort under the influence of mineral fertilizers, Topical issues of vegetable and horticulture. Anniversary readings, the collection of articles of All-Russian scientific-practical conference, 129$136(2009)$

3. A.V. Abramchuk, G.G. Kartasheva, Medicinal plants of the Urals, 552 (Yekaterinburg, 2010)

4. A. V. Abramchuk, G.G. Kartasheva, S. K. Mingalev, M. Y. Karpukhin, Medicinal flora of the Urals, 738 (Yekaterinburg, 2014)

5. Large illustrated encyclopedia. Medicinal plants, 224 (Saint Petersburg, NBSEA, 2015)

6. All about medicinal plants, 192 (St. Petersburg, "NBSEA" LLC, 2016)

7. Red Book of the Middle Urals (Sverdlovsk and Perm regions): Rare and endangered species of animals and plants, 279 (Yekaterinburg, Publishing house of the Ural University, 1996)

8. S.K. Mingalev, O.V. Brusnitsyna, Agrarian Education and Science, 1 (2019)

9. O. Kosakowska, K. Bączek, J.L. Przybył, et al., Molecules (Basel, Switzerland), 23 (7) (2018)

10. M. Grech-Baran., K. Sykłowska-Baranek, A. Pietrosiuk, Phytochemistry reviews, 14, 657-674 (2015)

11. Z. György, A Tolonen, M. Pakonen et al., Plant Science, 166 (2004)

12. Xu.Y. Jiang, H. Sun C., Yu, J., Xu, X., International Journal of Biological Macromolecules, 117, 167-178(2018)

13. Li. Y. Pham, V. Bui, M., et al., Current Pharmacology Reports, 3 (6), 384-395 (2017)

14. A. Coors, M. Brosch, E. Kahl, B. Gerber, Journal of Ethnopharmacology 235, 320-328 (2019)

15. J. Martin, Journal of Phytology, 2 (11), 80-87, (2010)

16. D.I. Ivanova, S.S. Boyadzieva, G. Angelov, et al. Bulgarian Chemical Communications, 50, 151-157(2018) 